\title{
Testing of DLR C/C-SiC and C/C for HIFiRE 8 Scramjet Combustor
}

\author{
David E. Glass * and Diego P. Capriotti ${ }^{\dagger}$ \\ NASA Langley Research Center, Hampton, VA 23681 USA \\ Thomas Reimer ${ }^{+}$and Marius Kütemeyer ${ }^{\S}$ \\ Deutsches Zentrum für Luft- und Raumfahrt (DLR), Pfaffenwaldring 38-40, Stuttgart, Germany \\ and \\ Prof. Michael Smart** \\ The University of Queensland, Brisbane, Australia
}

\begin{abstract}
Ceramic Matrix Composites (CMCs) have been proposed for use as lightweight hot structures in scramjet combustors. Previous studies have calculated significant weight savings by utilizing CMCs (active and passive) versus actively cooled metallic scramjet structures. Both a carbon/carbon $(\mathrm{C} / \mathrm{C})$ and a carbon/carbon-silicon carbide $(\mathrm{C} / \mathrm{C}-\mathrm{SiC})$ material fabricated by DLR (Stuttgart, Germany) are being considered for use in a passively cooled combustor design for Hypersonic International Flight Research Experimentation (HIFiRE) 8, a joint Australia / Air Force Research Laboratory hypersonic flight program, expected to fly at Mach 7 for $\sim 30 \mathrm{sec}$, at a dynamic pressure of $55 \mathrm{kPa}$. Flat panels of the DLR C/C and C/C-SiC materials were installed downstream of a hydrogen-fueled, dualmode sramjet combustor and tested for several minutes at conditions simulating flight at Mach 5 and Mach 6. Gaseous hydrogen fuel was used to fuel the sramjet combustor. The test panels were instrumented with embedded Type $K$ and Type $S$ thermocouples. Zirconia felt insulation was used during some of the tests to reduce heat loss from the back surface and thus increase the heated surface temperature of the $\mathrm{C} / \mathrm{C}-\mathrm{SiC}$ panel $\sim 177^{\circ} \mathrm{C}\left(3500^{\circ} \mathrm{F}\right)$. The final $\mathrm{C} / \mathrm{C}-\mathrm{SiC}$ panel was tested for three cycles totaling over $135 \mathrm{sec}$ at Mach 6 enthalpy. Slightly more erosion was observed on the $\mathrm{C} / \mathrm{C}$ panel than the $\mathrm{C} / \mathrm{C}$-SiC panels, but both material systems demonstrated acceptable recession performance for the HIFiRE 8 flight.
\end{abstract}

\section{Nomenclature}

ER $=$ Equivalence Ratio

FUELIP = Fuel Supply Pressure

$M \quad=$ Mach number

$P \quad=$ Pressure

$P_{0} \quad=$ total pressure

PTOTAL1 = Facility Total Pressure

$q_{\text {dot }}=$ heat flux

$T=$ Temperature

$T_{t} \quad=$ Total temperature

$T_{w} \quad=$ Temperature at wall surface

$x=$ distance from the facility nozzle exit plane (exit of the ramjet inlet)

$\phi_{H 2}=$ equivalence ratio of injected hydrogen fuel

\footnotetext{
* Project Engineer, Structural Mechanics and Concepts Branch, MS 190, Associate Fellow

${ }^{\dagger}$ Research Aerospace Engineer, Hypersonic Airbreathing Propulsion Branch, MS 168

Research Engineer, Institute of Structures and Design

${ }^{\S}$ Research Engineer, Institute of Structures and Design

** Professor and Chair of Hypersonic Propulsion, School of Mechanical and Mining Engineering, Senior Member
} 


\section{Approved for Public Release}

\section{Introduction}

$\mathrm{T}$ HE Hypersonic International Flight Research Experimentation (HIFiRE) Program is a collaboration between the Defence Science \& Technology Organisation (DSTO) of Australia and the United States Air Force through its Air Force Research Laboratory (AFRL). The primary objectives of the HIFiRE program are to investigate fundamental hypersonic phenomena and to develop and demonstrate component technologies that enable the sustained operation of aerospace systems within the atmosphere at speeds greater than Mach 5. The current manifest of the HIFiRE program includes nine flights yielding basic scientific data with analyses relevant to the design of future aerospace systems.

Completed flights in the HIFiRE program, such as HIFiRE $1^{1}$, have produced significant data on high-speed boundary layer transition. The launch technology used in HIFiRE is based around the sounding rocket approach developed during the HyShot Program at The University of Queensland ${ }^{2}$. Thus far, HIFiRE test technology has been used to test partially complete scramjet flowpaths that remain attached to the second stage booster. Furthermore, the trajectory for the tests has been ballistic, with the scramjet experiment conducted upon re-entry to the atmosphere at very high flight path angles. In contrast, the HIFiRE 8 vehicle, shown in Figure 1, is intended to cruise at Mach 7 under scramjet power for $30 \mathrm{sec}$ at approximately zero flight path angle. The more severe thermal environment of HIFiRE 8 relative to earlier HIFiRE flights results in the need for advanced thermal management

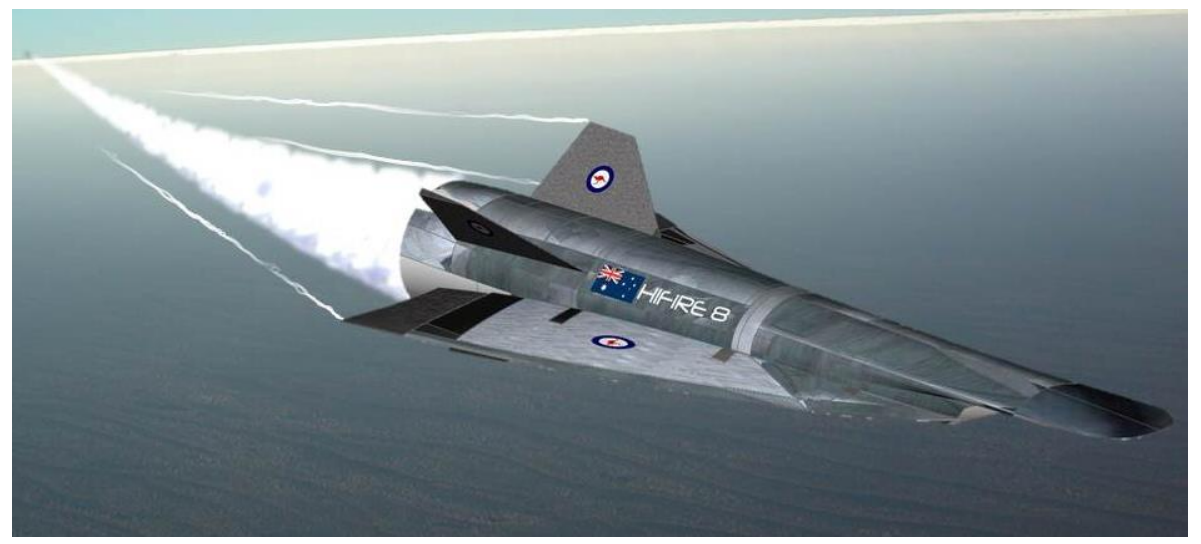

Figure 1. Image of the HIFiRE 8 flight vehicle. solutions.

State-of-the-art scramjet combustors utilize actively cooled metallic structures. However, ceramic matrix composites (CMC), due to their high temperature capabilities, have the potential to provide a passive alternative for at least a portion of the flowpath. Due to the relatively short test time $(\sim 30 \mathrm{sec})$ and single use nature of the HIFiRE 8 flight, a scramjet combustor constructed using a passive CMC material is being considered. Toward this end, flat panels of the DLR carbon/carbon-silicon carbide $(\mathrm{C} / \mathrm{C}-\mathrm{SiC})$ were tested in the NASA Langley Direct Connect Supersonic Combustion Test Facility (DCSCTF, see Reference 3) using the Durable Combustor Rig (DCR) test article. In addition to the $\mathrm{C} / \mathrm{C}-\mathrm{SiC}$, the DLR carbon/carbon (C/C) material was also tested.

\section{Test Facility and Test Article}

Tests of the DLR test articles were conducted in the DCSCTF. The facility is located in a 16- by 16 - by 52 -foot (4.8768- by 4.8768 - by 15.8496 -meter) test cell within Building 1221D at the NASA Langley Research Center in Hampton, Virginia. The facility has historically been used to test ramjet and scramjet flow paths at stagnation enthalpies duplicating that of flight at Mach numbers between 3.5 and 7.5. The facility is of a direct-connect, or connected-pipe, configuration such that the entire facility test gas mass flow passes through the flow path model; the flow at the exit of the facility nozzle simulates the flow entering the isolator of a ramjet or scramjet in flight. The stagnation enthalpy necessary to simulate the flight Mach number for the test is achieved through hydrogen-air combustion with oxygen replenishment to obtain a test gas with the same oxygen mole or mass fraction as atmospheric air (0.2095 or 0.2314, respectively). A schematic of the DCSCTF is shown in Figure 2. 


\section{Approved for Public Release}

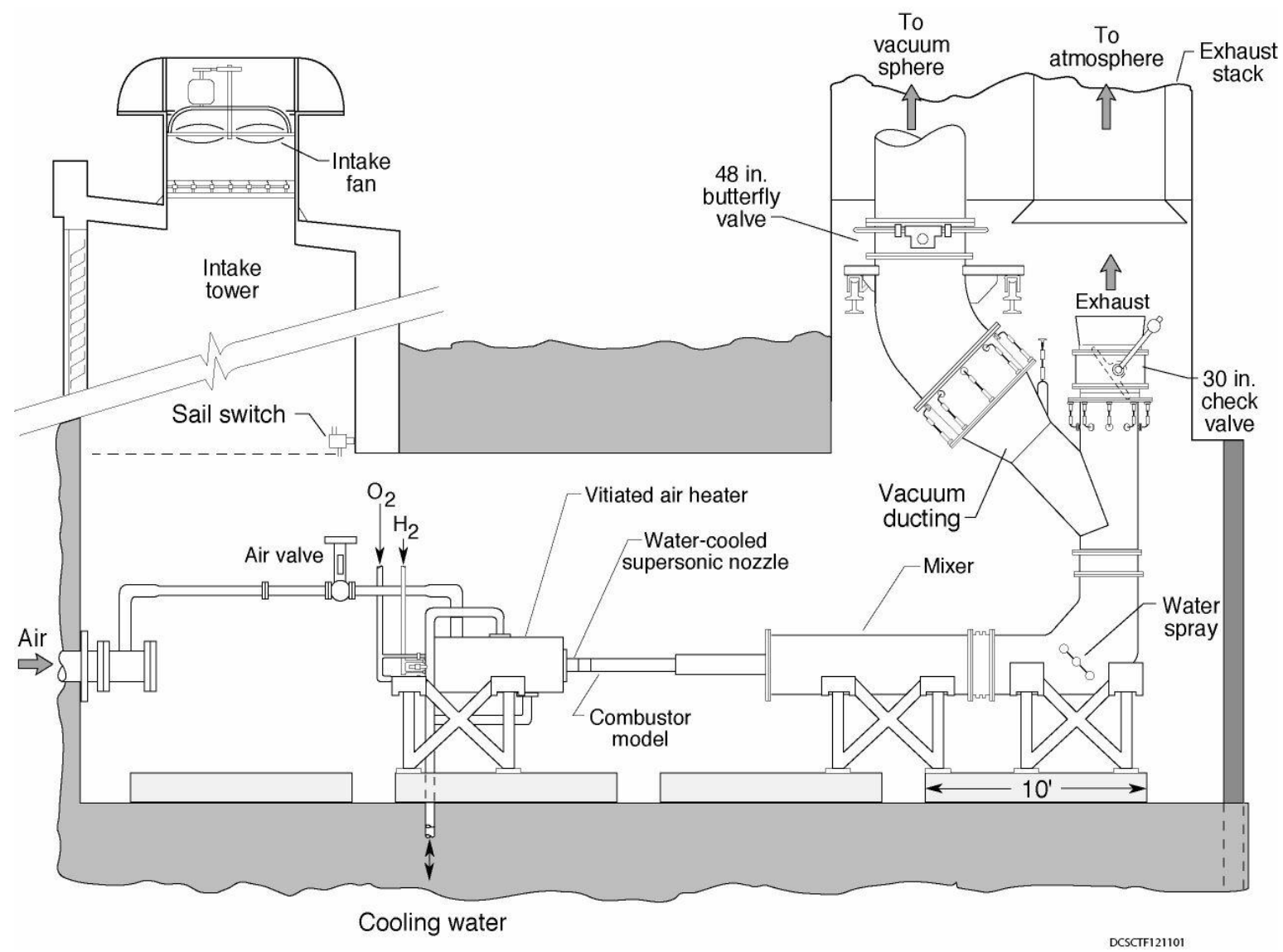

Figure 2. Schematic of the NASA Langley DCSCTF.

The facility water-cooled combustion heater is supplied air from a 600-psig (4.1 mPa) high-pressure bottle field while hydrogen and oxygen are supplied from 2400-psig $(16.5-\mathrm{mPa})$ tube trailers. Within the vitiated heater, oxygen is mixed with air before burning with hydrogen to increase the stagnation enthalpy of the flow. The vitiated air is then passed through a water-cooled supersonic nozzle, which is directly upstream of the test article. After passing through the test article, the flow enters the facility mixer where the exhaust test gas is cooled by water injection before eventually emptying into a 70-foot-diameter (21.3-m-diameter) vacuum sphere. Using two water-cooled facility nozzles, a Mach 2.1 and a Mach 2.65, the DCSCTF can deliver flow fields that simulate the flow entering a ramjet or scramjet combustor at flight Mach numbers between 5 and 7. For the composite panel tests conducted, the Mach 2.1 nozzle was used at Mach 5 and 6 flight enthalpies. A summary of the nominal facility simulation points utilized is presented in Table 1. The hardware installed in the DCSCTF for these tests comprised of existing hardware (Figure 3), and components fabricated especially for these tests. The existing hardware included a water cooled isolator and fuel injector block fabricated from thick walled copper, and an un-cooled divergent combustor also made of copper, but with a sprayed zirconia thermal barrier coating. The injector block contained a highly effective injection scheme that was able to inject and effectively mix and burn gaseous hydrogen fuel to simulate the conditions of a real combustor.

Table 1. Test conditions.

\begin{tabular}{|c|c|c|c|c|c|c|c|}
\hline $\begin{array}{c}\text { Simulated } \\
\text { Flight Mach } \\
\begin{array}{c}\text { Number } \\
(\text { at } 1000 \mathrm{psf})\end{array}\end{array}$ & $\begin{array}{c}\text { Facility } \\
\text { Total } \\
\text { Pressure } \\
(\mathrm{psia})\end{array}$ & $\begin{array}{c}\text { Facility Total } \\
\text { Temperature } \\
\left({ }^{\circ} \mathrm{R}\right)\end{array}$ & $\begin{array}{c}\text { Facility Total } \\
\text { Enthalpy } \\
\left(\mathrm{BTU} / \mathrm{lb}_{\mathrm{m}}\right)\end{array}$ & $\begin{array}{c}\text { Facility } \\
\text { Nozzle } \\
\text { Exit Mach } \\
\text { number }\end{array}$ & $\begin{array}{c}\text { Facility } \\
\text { Nozzle Exit } \\
\text { Pressure } \\
(\mathrm{psia})\end{array}$ & $\begin{array}{c}\text { Facility } \\
\text { Mass } \\
\text { Flow Rate } \\
\left(\mathrm{lb}_{\mathrm{m}} / \mathrm{s}\right)\end{array}$ & $\begin{array}{c}\text { Test gas } \\
\text { water } \\
\text { mole } \\
\text { fraction }\end{array}$ \\
\hline 5 & 94.8 & 2103 & 574 & 2.12 & 10.0 & 8.08 & 12.7 \\
\hline 6 & 91.4 & 2721 & 793 & 2.10 & 10.0 & 6.73 & 18.5 \\
\hline
\end{tabular}




\section{Approved for Public Release}

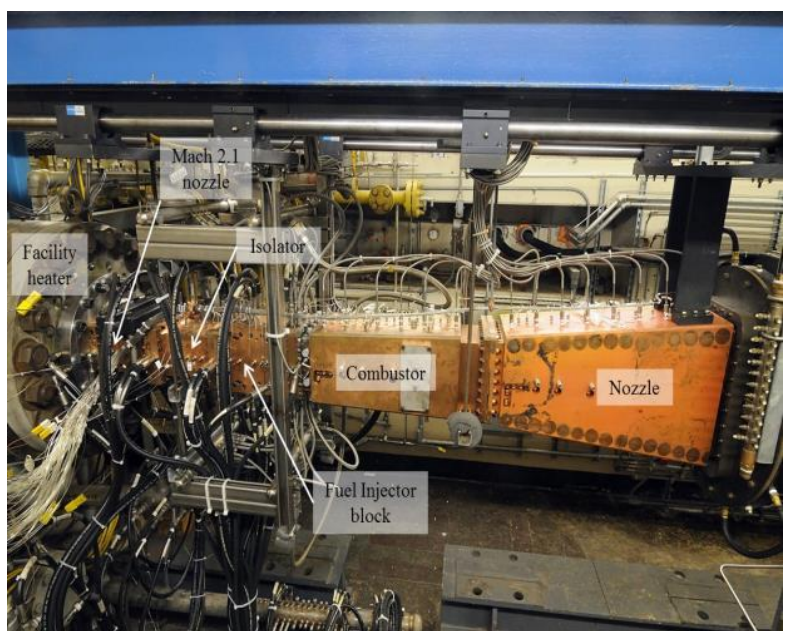

Figure 3. Photograph of DCR test hardware.

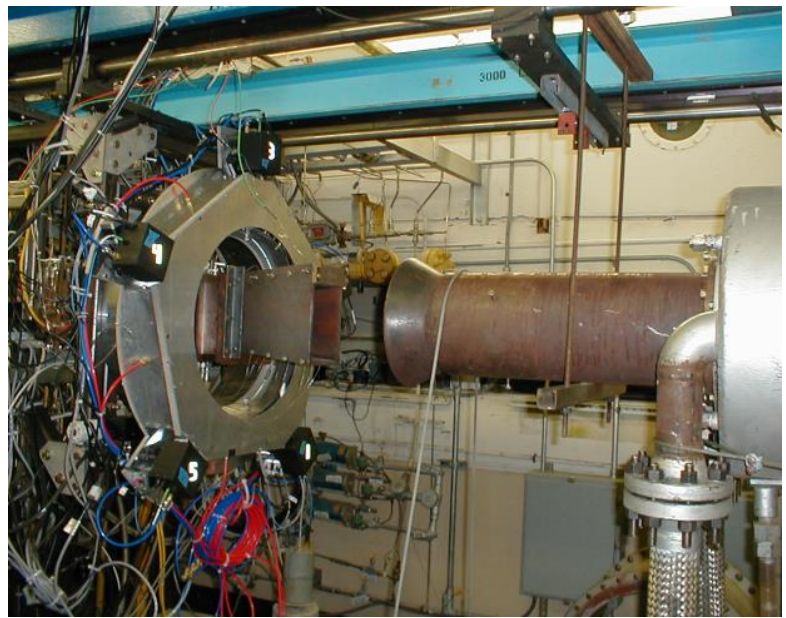

Figure 4. View of nozzle exit and exhaust duct installed in the DCSCTF.
The new hardware consisted of a $6^{\circ}$ divergent nozzle with the CMC panel installed on the top surface, and a steel plate on the bottom. The facility flowpath had a constant width of 5.21 inches $(13.2 \mathrm{~cm})$, and included pressure taps on both the top and bottom surfaces, except on the CMC panel. The CMC panel was instrumented with thermocouples (TCs) attached to the back side. Figure 4 shows an image of the nozzle exit, with a catch cone in place to collect the exhaust. Figure 5 shows a close-up view of the exhaust nozzle with the CMC plate installed as the top expanding surface.

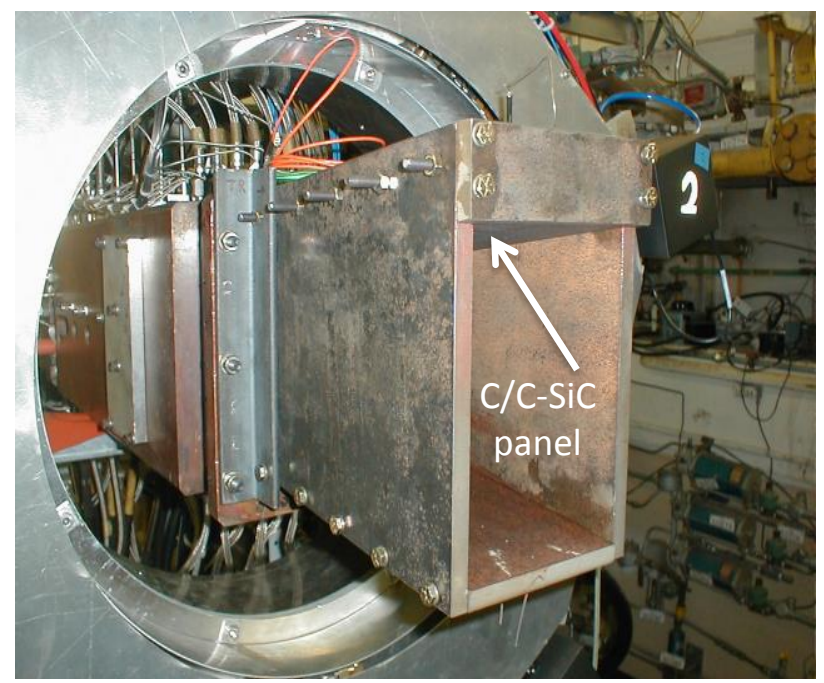

Figure 5. C/C-SiC panel mounted as the top wall of the 10-inch-long (25.4-cm-long), $6^{\circ}$ diverging nozzle duct.

\section{Characterization of the Test Flow Conditions}

Using the inflow conditions, the measured wall pressures, the local duct area, the mass of fuel added, and estimates of the viscous drag and heat loss, the 1-D flow properties in the duct can be calculated. In the region where the CMC panel was installed $\left(\mathrm{x}=43\right.$ inches $(109.2 \mathrm{~cm})$ ), the total temperature of the flow was $\mathrm{T}_{\mathrm{t}}=3900^{\circ} \mathrm{R}(2167 \mathrm{~K})$, the static temperature was $\mathrm{T}=3200^{\circ} \mathrm{R}(1778 \mathrm{~K})$, the static pressure was $\mathrm{P}=15 \mathrm{psia}(103 \mathrm{kPa})$ and the Mach number was $\mathrm{M}=1.35$. Based on a calculation of the facility boundary layer performed using the Van Driest II method, the heat load applied to a wall at $\mathrm{T}_{\mathrm{w}}=540^{\circ} \mathrm{R}(300 \mathrm{~K})$ in the region of the CMC panel was $\mathrm{q}_{\text {dot }}\left(\mathrm{T}_{\mathrm{w}}=300 \mathrm{~K}\right) \sim 1.4 \mathrm{MW} / \mathrm{m}^{2}$. Due to the higher total enthalpy, more fuel could be added in the combustor without disrupting the test, and typical fueling was at $\phi_{\mathrm{H} 2}=1.01$. At $\mathrm{x}=43$ inches $(109.22 \mathrm{~cm})$, the 1-D flow properties for these tests were $\mathrm{T}_{\mathrm{t}}=4500^{\circ} \mathrm{R}$ $(2500 \mathrm{~K}), \mathrm{T}=3800^{\circ} \mathrm{R}(2111 \mathrm{~K}), \mathrm{P}=14 \mathrm{psia}(96 \mathrm{kPa})$ and $\mathrm{M}=1.35$. The estimated heat load seen by the $\mathrm{CMC}$ panel in this case was estimated to be $\mathrm{q}_{\mathrm{dot}}\left(\mathrm{T}_{\mathrm{w}}=300 \mathrm{~K}\right) \sim 1.9 \mathrm{MW} / \mathrm{m}^{2}$. 


\section{Fabrication of DLR C/C-SiC and C/C Composite Panels}

Ceramic matrix composites have been proposed for use as thermal protection materials and hot structures. At the Institute of Structures and Design of DLR in Stuttgart, a specific CMC variant, $\mathrm{C} / \mathrm{C}-\mathrm{SiC}$ has been developed consisting mainly of carbon fibers embedded in a silicon carbide matrix. ${ }^{4}$ The fabrication of $\mathrm{C} / \mathrm{C}-\mathrm{SiC}$ CMC composites at DLR is divided into three steps, as indicated in Figure 6. In the first step, a carbon fiber reinforced plastic (CFRP) component is produced, which can be performed in different ways. The preferred approach is resin transfer molding (RTM) or using autoclave technology, but warm pressing or filament winding are also acceptable processes. After the curing, the composites are tempered for 4 hours at $240^{\circ} \mathrm{C}$ $\left(464^{\circ} \mathrm{F}\right)$ to complete the polymerization of the matrix. It is essential to use a resin (e.g., phenolic) with high carbon yield in this step to create a matrix with sufficient

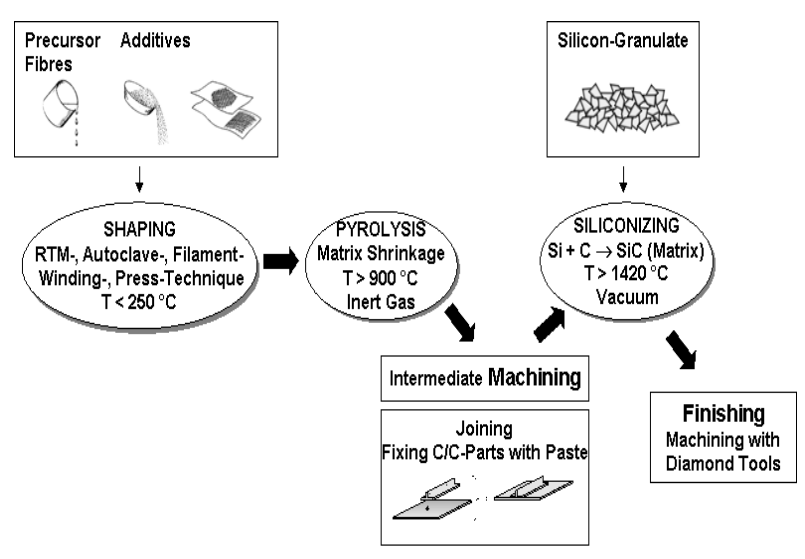

Figure 6. Schematic diagram of fabrication process. carbon content in the subsequent step.

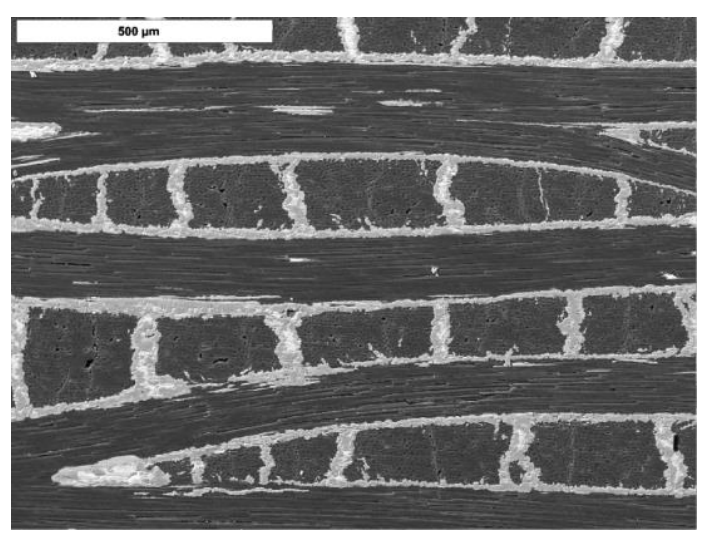

Figure 7. Typical microstructure of $\mathrm{C} / \mathrm{C}-\mathrm{SiC}$ : black color, fiber bundles with carbon matrix between fibers; medium grey, silicon carbide matrix; light grey/white, free silicon (scale bar is $500 \mu \mathrm{m}$ ).
In the second step, the CFRP composite is carbonized under inert atmosphere (nitrogen) at a temperature of $1650^{\circ} \mathrm{C}$ $\left(3002^{\circ} \mathrm{F}\right)$ to convert the polymer matrix to amorphous carbon. The result is a $\mathrm{C} / \mathrm{C}$ component. The pyrolysis results in a macroscopic shrinkage of about $10 \%$ mainly in thickness and a microscopic network of cracks within the $\mathrm{C} / \mathrm{C}$ composite is formed. The fiber bundles remain practically intact.

The fabrication of the $\mathrm{C} / \mathrm{C}$ plates is similar to that of the $\mathrm{C} / \mathrm{C}-\mathrm{SiC}$ plates through the first pyrolysis, the second step above. The result is a higher porosity and lower density $\mathrm{C} / \mathrm{C}$ than a reinifiltrated $\mathrm{C} / \mathrm{C}$ or siliconized $\mathrm{C} / \mathrm{C}-\mathrm{SiC}$. In this case, however, the plates were reinfiltrated two more times with phenolic resin to increase the density and lower the porosity. In addition to the absence of $\mathrm{Si}$ and $\mathrm{SiC}$, the $\mathrm{C} / \mathrm{C}$ plates differ in the manufacturing of the initial CFRP. The C/C plates are warm pressed using short carbon fiber and phenolic resin, while the $\mathrm{C} / \mathrm{C}-\mathrm{SiC}$ plates are composed of carbon fiber weaves cured and infiltrated via autoclove.

In the third step, the $\mathrm{C} / \mathrm{C}$ component is siliconized via melt infiltration. The component is placed into a coated graphite crucible and solid silicon is added as granulated pure metal. After heating to over $1420^{\circ} \mathrm{C}\left(2588^{\circ} \mathrm{F}\right)$ (melting of silicon), the porous $\mathrm{C} / \mathrm{C}$ component fills with liquid silicon due to the capillary effect of the micro-cracks and the low viscosity of the molten silicon. In an exothermic reaction between the molten silicon and the carbon matrix, silicon carbide is formed along the micro cracks encapsulating the carbon fiber bundles. The siliconizing is carried out under vacuum at a temperature of $1650^{\circ} \mathrm{C}\left(3002^{\circ} \mathrm{F}\right)$. The resulting $\mathrm{C} / \mathrm{C}-\mathrm{SiC}$ composites contain three material phases. These are the carbon phase consisting of carbon fibers and residual carbon matrix, silicon carbide as the main matrix constituent, and a small share of unreacted free silicon, as shown in Figure 7. The typical thermal and mechanical properties of the $\mathrm{C} / \mathrm{C}-\mathrm{SiC}$ material are shown in Table 2. 
Table 2. C/C-SiC properties.

\begin{tabular}{|c|c|c|c|c|}
\hline Property & Direction & Value & Unit & Temperature \\
\hline Density & & 1900 & $\mathrm{~kg} / \mathrm{m}^{3}$ & \\
\hline Young's Modulus & 1 & 60 & $\mathrm{GPa}$ & \\
\hline & 2 & 60 & $\mathrm{GPa}$ & \\
\hline & 3 & 20 & $\mathrm{GPa}$ & \\
\hline Shear Modulus & 12 & 8.8 & $\mathrm{GPa}$ & \\
\hline & 23 & 8.9 & $\mathrm{GPa}$ & \\
\hline & 13 & 8.8 & $\mathrm{GPa}$ & \\
\hline & 12 & 0.032 & & \\
\hline Poisson's ratio & 23 & 0.032 & & \\
\hline & 13 & 0.032 & & \\
\hline & 12 & $0.5 \mathrm{E}-06$ & & $20^{\circ} \mathrm{C} ; 68^{\circ} \mathrm{F}$ \\
\hline CTE & 12 & $2.5 \mathrm{E}-06$ & & $1600^{\circ} \mathrm{C} ; 2912^{\circ} \mathrm{F}$ \\
\hline Thermal Conductivity & 1 & 18 & $\mathrm{~W} / \mathrm{mK}$ & \\
\hline & 2 & 18 & $\mathrm{~W} / \mathrm{mK}$ & \\
\hline & 3 & 9 & $\mathrm{~W} / \mathrm{mK}$ & \\
\hline & & 1000 & $\mathrm{~J} / \mathrm{kgK}$ & $20^{\circ} \mathrm{C} ; 68^{\circ} \mathrm{F}$ \\
\hline Specific Heat & & 1800 & $\mathrm{~J} / \mathrm{kgK}$ & $1600^{\circ} \mathrm{C} ; 2912^{\circ} \mathrm{F}$ \\
\hline & & 0.75 & & $20^{\circ} \mathrm{C} ; 68^{\circ} \mathrm{F}$ \\
\hline Emissivity, total & & 0.8 & & $1000^{\circ} \mathrm{C} ; 1832^{\circ} \mathrm{F}$ \\
\hline & & 0.85 & & $1600^{\circ} \mathrm{C} ; 2912^{\circ} \mathrm{F}$ \\
\hline
\end{tabular}

Plate material with fibers in 1-direction and 2-direction. No fibers in 3-direction (plate thickness)

\section{Test Article Instrumentation}

The $\mathrm{C} / \mathrm{C}-\mathrm{SiC}$ and $\mathrm{C} / \mathrm{C}$ panels were instrumented at DLR prior to testing at NASA Langley. The panels were $254 \mathrm{~mm}$ (10 in.) long and $145 \mathrm{~mm}$ (5.7 in.) wide, with a thickness of $8 \mathrm{~mm}(0.315 \mathrm{in}$.). The short edges were inclined slightly at an angle of $6^{\circ}$ due to interface reasons with the DCSCTF facility. The panels were machined on one side (the backside) to achieve the thickness. The other side remained in the as-fired condition as the plates come out of the processing. On the as-fired side (flow path side) only a few drops of excess silicon were removed. The reason for not machining both sides was that on the as-fired side there remains a thin scale of continuous $\mathrm{SiC}$ over the plate (which protects the panel fibers) whereas the machining exposes the carbon fibers to the hot combusting flow field. On the backside, grooves were machined for the installation of two thermocouples (Figure 8).

On each panel, two TCs were mounted. A curved groove was machined for each TC, as shown in Figure 9. The depth of the groove was $2 \mathrm{~mm}(0.079 \mathrm{in}$.). The TC tip was fixed in the groove with a graphite-based adhesive. Type $\mathrm{K}$ and Type $\mathrm{S}$ TCs of $1 \mathrm{~mm}$ (0.039 in.) diameter were installed. Table 3 gives the details about which TC type was installed in which

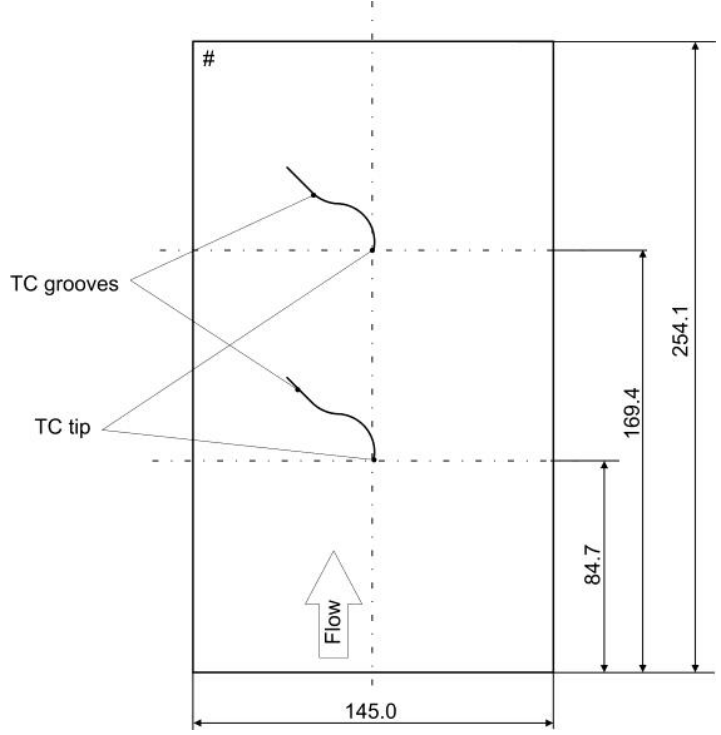

Figure 8. Location of the TCs as seen from backside (units in $\mathbf{m m}$ ). 


\section{Approved for Public Release}

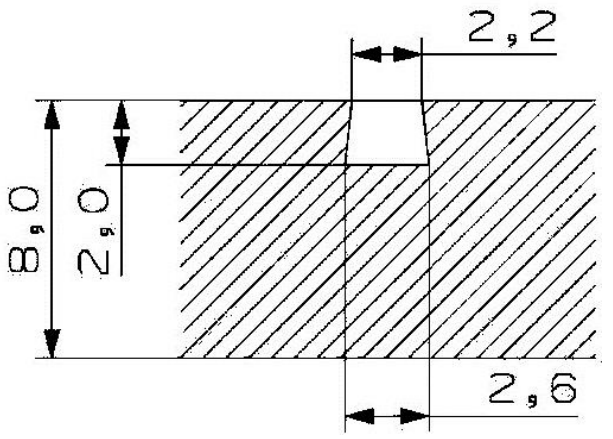

Figure 9. Cross section of TC groove (units in $\mathbf{m m})$.

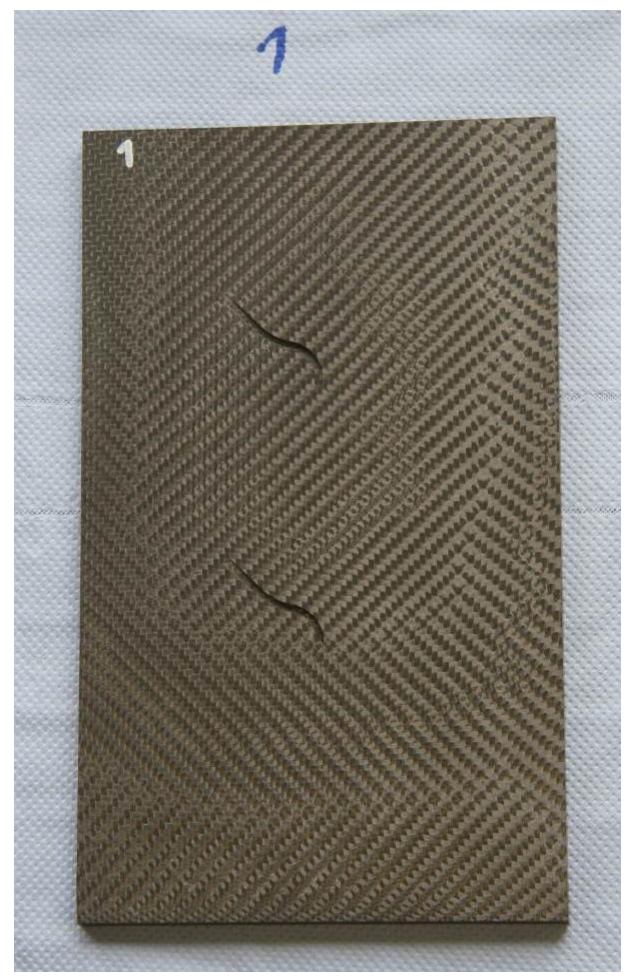

Figure 10. Panel seen from machined side with TC grooves.
Table 3. Panels indicating type of TC installed.

\begin{tabular}{|c|c|c|c|}
\hline Panel No. & Type $\mathbf{K}$ & Type $\mathbf{S}$ & Test load level \\
\hline $\mathbf{1}$ & 1 & 1 & medium/ high \\
\hline $\mathbf{2}$ & 2 & 0 & low \\
\hline $\mathbf{3}$ & 1 & 1 & medium/high \\
\hline $\mathbf{4}$ & 1 & 1 & spare \\
\hline
\end{tabular}

In order to provide support in addition to the graphite adhesive, the grooves were machined as dovetail grooves with an S-curve as detailed in the following cross section sketch. The TCs were

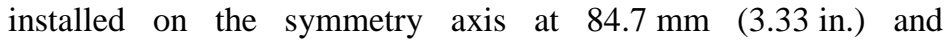
$169.4 \mathrm{~mm}(6.67 \mathrm{in}$.) from the edge, lengthwise (Figure 8). Figure 10 through Figure 12 illustrate the installation of the TCs.

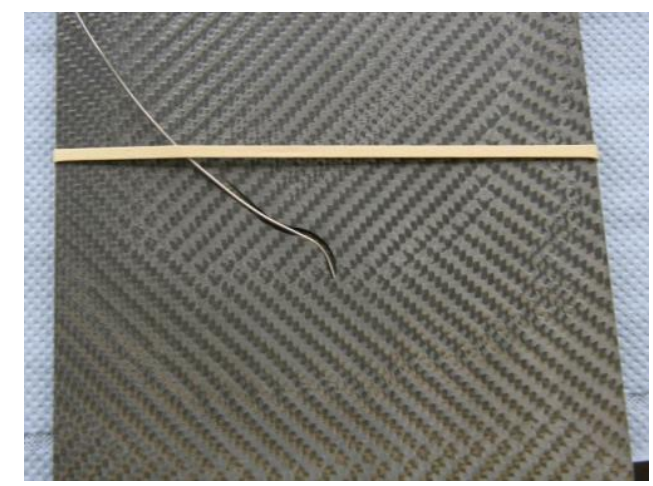

Figure 11. TC inserted into groove.

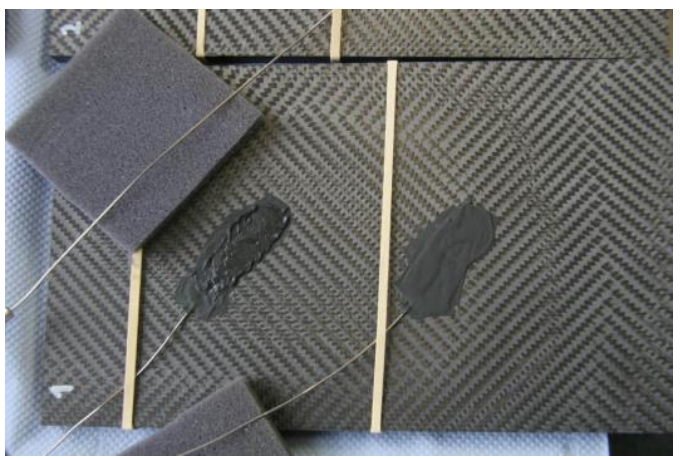

Figure 12. Graphite adhesive applied on TC tips.

\section{Test Results}

The test matrix is shown in Table 4. Three C/C-SiC and one C/C panels were tested, with multiple tests per panel. The test hardware was allowed to cool down for approximately 20 minutes between tests. The facility run number is shown, followed by the simulated flight Mach number, either Mach 5 or 6 . The actual (aerodynamic) Mach number of the flowfield within the DCR was $\sim$ Mach 2. As mentioned previously, two TC's were embedded in the panel from the back surface. In each of the panels tested, there was one Type K and one Type S TC installed. Shown in the table are the temperatures of the TC at the end of each test. The facility total temperature and pressure are also shown in the table, along with the equivalence ratio (ER) of the injected hydrogen fuel. Finally, the fuel-on time and the total test duration are shown. 
Table 4. Test Matrix

\begin{tabular}{|c|c|c|c|c|c|c|c|c|c|c|c|c|}
\hline \multirow{2}{*}{ Panel } & \multirow{2}{*}{$\begin{array}{l}\text { Run } \\
\text { No. }\end{array}$} & \multirow{2}{*}{$\begin{array}{c}\text { Simulated } \\
\text { Flight } \\
\text { Mach No. }\end{array}$} & \multicolumn{2}{|c|}{$\begin{array}{l}\text { Temperature at } \\
\text { end of Test, }{ }^{\circ} \mathbf{R}\end{array}$} & \multicolumn{2}{|c|}{$\begin{array}{l}\text { Temperature at } \\
\text { end of Test, }{ }^{\circ} \mathbf{C}\end{array}$} & \multirow{2}{*}{$\begin{array}{c}\mathbf{P}_{0} \\
\text { psia }\end{array}$} & \multicolumn{2}{|c|}{$\mathbf{T}_{0}$} & \multirow{2}{*}{$\begin{array}{c}\text { ER } \\
\text { (ramp + } \\
\text { film) }\end{array}$} & \multirow{2}{*}{$\begin{array}{c}\text { Fuel-on } \\
\text { Time } \\
\text { [sec] }\end{array}$} & \multirow{2}{*}{$\begin{array}{c}\text { Total Test } \\
\text { Duration } \\
\text { [sec] }\end{array}$} \\
\hline & & & Type K & Type S & Type K & Type S & & ${ }^{\circ} \mathbf{R}$ & ${ }^{\circ} \mathbf{C}$ & & & \\
\hline \multirow{8}{*}{ C/C HP635-7 } & 68 & 5 & 859 & 858 & 204 & 204 & 96.1 & 2131 & 911 & & $\mathrm{n} / \mathrm{a}$ & 20 \\
\hline & 69 & 5 & 1507 & 1450 & 564 & 532 & 96.1 & 2117 & 903 & 0.556 & 35 & 40 \\
\hline & 70 & 5 & 1611 & 1548 & 622 & 587 & 95.9 & 2130 & 910 & 0.741 & 35 & 40 \\
\hline & 71 & 6 & 1002 & 1031 & 284 & 300 & 89.4 & 2546 & 1141 & & $\mathrm{n} / \mathrm{a}$ & 20 \\
\hline & 72 & 6 & 1878 & 1796 & 770 & 725 & 91.8 & 2611 & 1177 & 0.986 & 40 & 45 \\
\hline & 73 & 6 & 1026 & 1015 & 297 & 291 & 88.8 & 2558 & 1148 & & $\mathrm{n} / \mathrm{a}$ & 20 \\
\hline & 74 & 6 & 1987 & 1800 & 831 & 727 & 91.6 & 2594 & 1168 & 1.003 & 39 & 44 \\
\hline & 75 & 6 & 2051 & 1835 & 866 & 746 & 90.8 & 2626 & 1186 & 1.023 & 39 & 44 \\
\hline \multirow{8}{*}{ C/C-SiC \#4 } & 52 & 5 & 1005 & 972 & 285 & 267 & 92 & 1939 & 804 & & $\mathrm{n} / \mathrm{a}$ & 20 \\
\hline & 53 & 5 & 1248 & 1193 & 420 & 390 & 91.6 & 1957 & 814 & & $\mathrm{n} / \mathrm{a}$ & 40 \\
\hline & 54 & 5 & 997 & 971 & 281 & 266 & 91.8 & 1989 & 832 & & $\mathrm{n} / \mathrm{a}$ & 20 \\
\hline & 55 & 5 & 1214 & 1329 & 401 & 465 & 92.6 & 2020 & 849 & 0.53 & 14 & 20 \\
\hline & 56 & 5 & 1044 & 1062 & 307 & 317 & 94.2 & 2035 & 857 & & $\mathrm{n} / \mathrm{a}$ & 20 \\
\hline & 57 & 5 & 1737 & 1834 & 692 & 746 & 94.5 & 2070 & 877 & 0.58 & 32.5 & 38.5 \\
\hline & 58 & 5 & 1076 & 1087 & 325 & 331 & 94.2 & 2070 & 877 & & $\mathrm{n} / \mathrm{a}$ & 20 \\
\hline & 60 & 5 & 1010 & 999 & 288 & 282 & 94.6 & 2059 & 871 & & $\mathrm{n} / \mathrm{a}$ & 20 \\
\hline \multirow{3}{*}{$\mathrm{C} / \mathrm{C}-\mathrm{SiC} \# 3$} & 62 & 6 & 1281 & 1291 & 439 & 444 & 90.6 & 2624 & 1185 & & $\mathrm{n} / \mathrm{a}$ & 20 \\
\hline & 63 & 6 & 1295 & 1319 & 446 & 460 & 90.7 & 2647 & 1197 & & $\mathrm{n} / \mathrm{a}$ & 20 \\
\hline & 64 & 6 & 2025 & 2206 & 852 & 952 & 90.6 & 2648 & 1198 & 1.01 & 30 & 40 \\
\hline \multirow{4}{*}{ C/C-SiC \#1 } & 76 & 6 & 1382 & 1317 & 495 & 459 & 89.6 & 2591 & 1166 & & $\mathrm{n} / \mathrm{a}$ & 20 \\
\hline & 77 & 6 & 2352 & 2515 & 1034 & 1124 & 91.9 & 2599 & 1171 & 1.009 & 39 & 44 \\
\hline & 78 & 6 & 2342 & 2504 & 1028 & 1118 & 91.2 & 2639 & 1193 & 1.039 & 39.5 & 44.5 \\
\hline & 79 & 6 & 2336 & 2462 & 1025 & 1095 & 91.9 & 2654 & 1201 & 1.047 & 39.5 & 44.5 \\
\hline
\end{tabular}

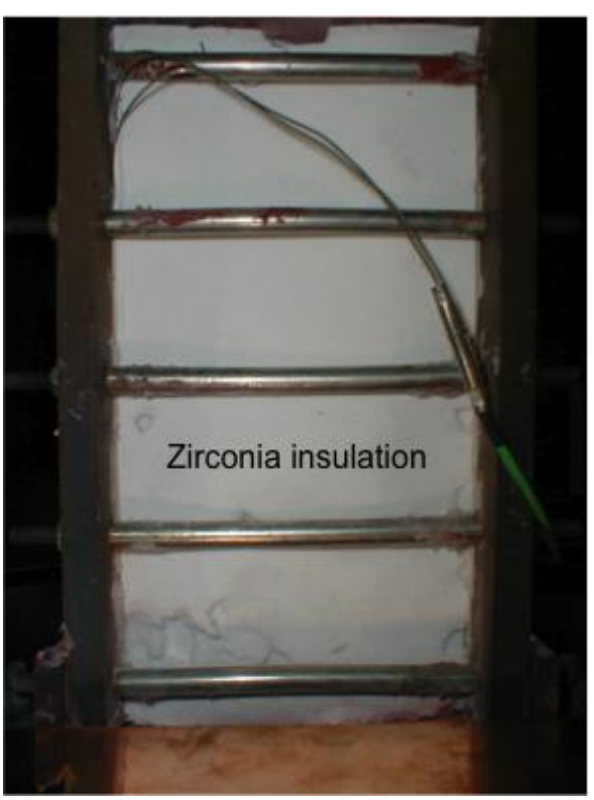

Figure 13. Photograph of zirconia insulation on cool surface of test panel.

the photograph.

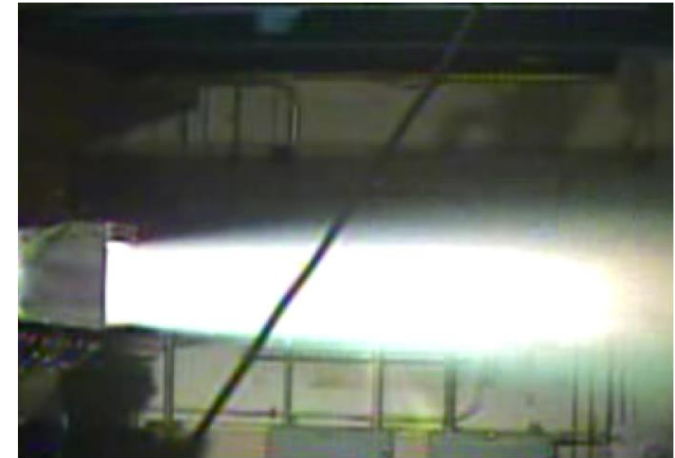

Figure 14. Photograph of scramjet exhaust during Run 79.

In an effort to increase the hot surface temperature on the final test panel (Runs 76-79), zirconia insulation was placed on the cool surface of the panel (backside). A photograph of the zirconia insulation on the test panel is shown in Figure 13. The insulation increased the hot surface temperature by $\sim 177^{\circ} \mathrm{C}\left(350^{\circ} \mathrm{F}\right)$. A photograph of the scramjet exhaust during Run 79 (final test with $\mathrm{C} / \mathrm{C}$-SiC panel) is shown in Figure 14. Flow is left-to-right with the test panel on the upper surface of the fixture on the left hand side of

8

American Institute of Aeronautics and Astronautics 
A plot of the data from the two embedded TC's is show in Figure 15 (for Run 79). The Type S TC reads a higher temperature, and was located upstream of the Type K TC. The facility total pressure (PTOTAL1) and fuel supply pressure (FUEL1P) are also shown on the figure. A post-test photograph of the test panel heated surface is also shown on the figure.

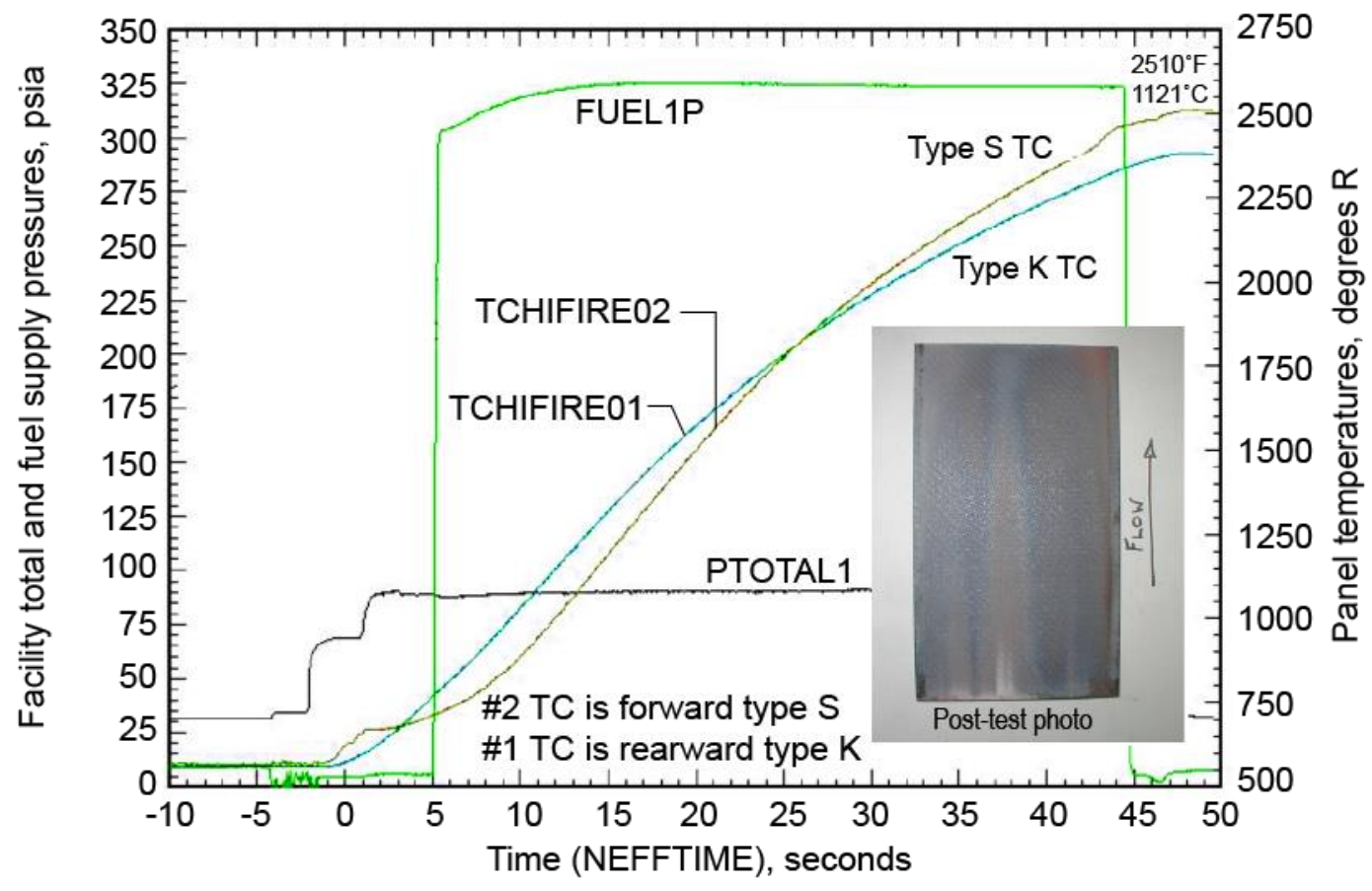

Figure 15. C/C-SiC panel test temperatures during Run 79.

After the final run, the test panel was removed from the carbon steel fixture. Figure 16 (a) shows a photograph of the fixture with the test panel removed. The red room-temperature vulcanizing (RTV) sealant (hightemperature silicone) can be seen in the photograph. Figure 16 (b) shows a close-up photograph of the corner region where the test panel was inserted into the groove on the right hand side. Seen in Figure $16(\mathrm{~b})$ is the melted carbon steel at the upstream edge of the fixture. Despite the high heating that the panel was subjected to during the last test and the melting of the steel sidewalls, the panel showed practically no damage, just a slight stain where the melted

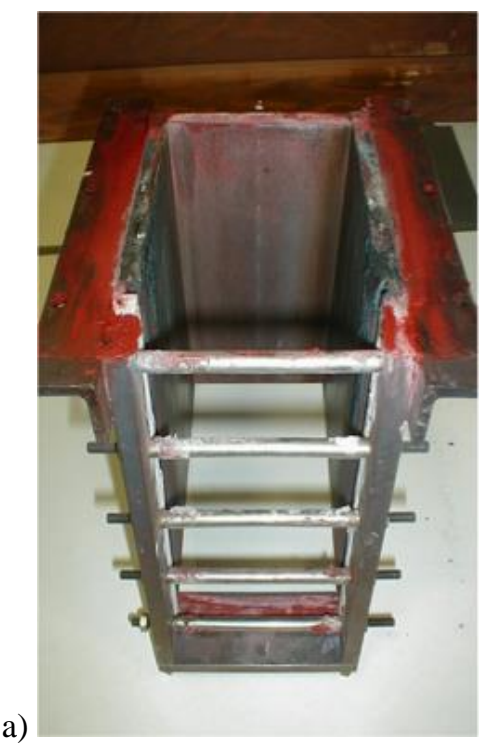

b)

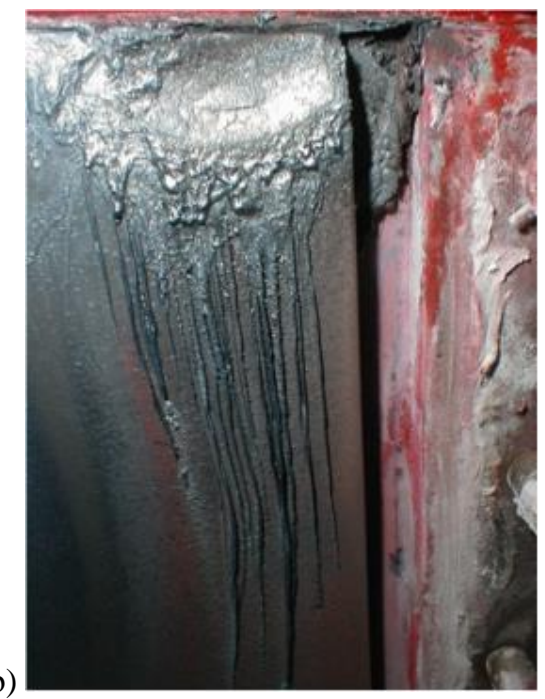

Figure 16. a) Photograph of test fixture after final test, and b) Close-up photograph after final test showing melted carbon steel fixture on test panel. steel contacted with the panel.

Figure 17 shows a photograph of both the hot and cool side of $\mathrm{C} / \mathrm{C}$-SiC panel \#1 after the final test. As indicated by the recession measurements and the post-test photographs of the panel, the panel survived the series of tests with negligible deterioration. 

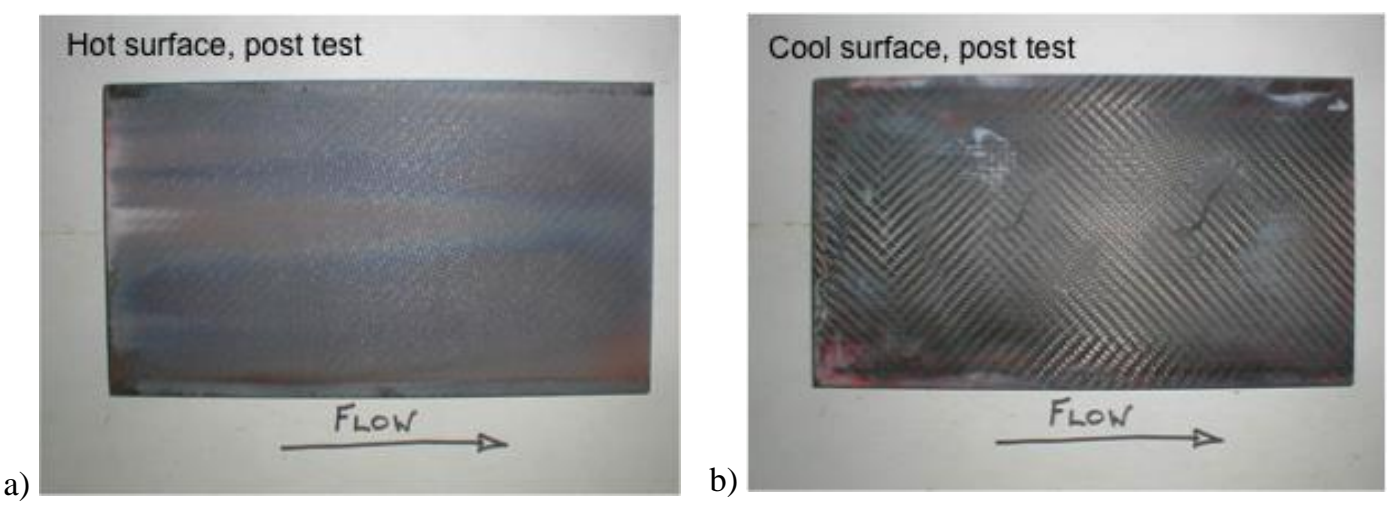

Figure 17. Photograph of a) hot surface and b) cool surface after Run 79.

Table 5 shows the pre- and post-test thickness measurements, taken prior to the first run with panel $\mathrm{C} / \mathrm{C}$-SiC \#1 and taken again after the last run with $\mathrm{C} / \mathrm{C}-\mathrm{SiC} \# 1$. Very little recession was measured on the test panels. Figure 18 shows the recession (change in thickness, $\Delta \mathrm{t}$ ) at eight locations on the panel after Run 79. The largest recession was $0.051 \mathrm{~mm}(0.002 \mathrm{in}$.). Several locations have zero recession.

Table 5. Pre-and post-test thickness measurements for C/C-SiC panel \#1.

\begin{tabular}{|c|c|c|c|c|c|c|c|c|}
\hline & \multicolumn{9}{|c|}{ Thickness (mm)/ Measurement location } \\
\hline & $\mathbf{1}$ & $\mathbf{2}$ & $\mathbf{3}$ & $\mathbf{4}$ & $\mathbf{5}$ & $\mathbf{6}$ & $\mathbf{7}$ & $\mathbf{8}$ \\
\hline Pre-test & 8.026 & 8.052 & 8.052 & 8.103 & 8.306 & 8.280 & 8.052 & 8.052 \\
\hline Post-test & 8.026 & 8.001 & 8.026 & 8.077 & 8.306 & 8.255 & 8.026 & 8.052 \\
\hline
\end{tabular}

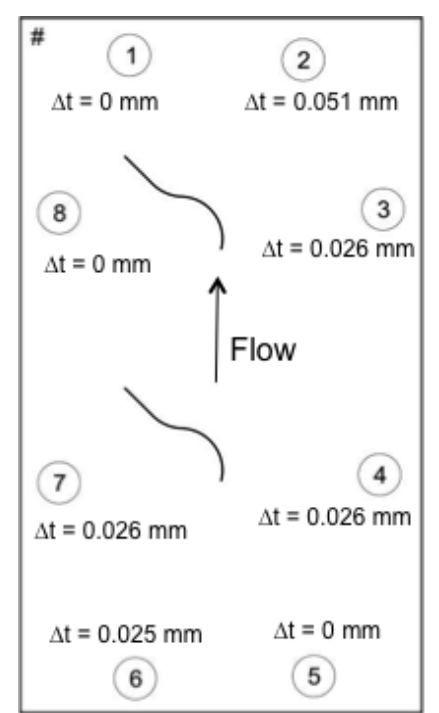

Figure 18. Recession measured after Run 79 for C/C-SiC panel \#1.
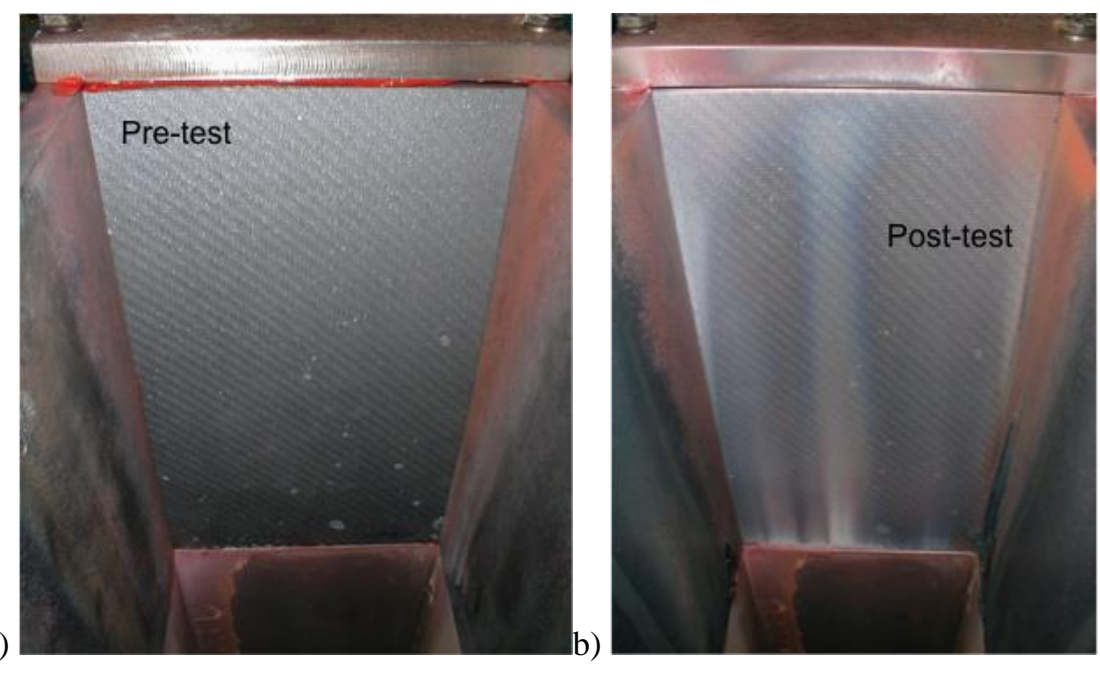

Figure 19. Pre- and post-test photograph of $\mathrm{C} / \mathrm{C}$-SiC panel installed in test fixture.

Photographs of the C/C-SiC panel 1 prior to testing and after the series of tests, are shown in Figure 19 (a). The discoloration shown in Figure 19 (b) is due to melting of the carbon steel support structure.

After the $\mathrm{C} / \mathrm{C}-\mathrm{SiC}$ panels were tested, a single C/C panel from DLR was also tested. A plot of the two embedded TC's is show in Figure 20. The Type S TC reads a higher temperature, and was located upstream of the Type K TC. The facility total and fuel supply pressures are also shown on the figure. A photograph of the test panel post-test is also shown on the figure. 


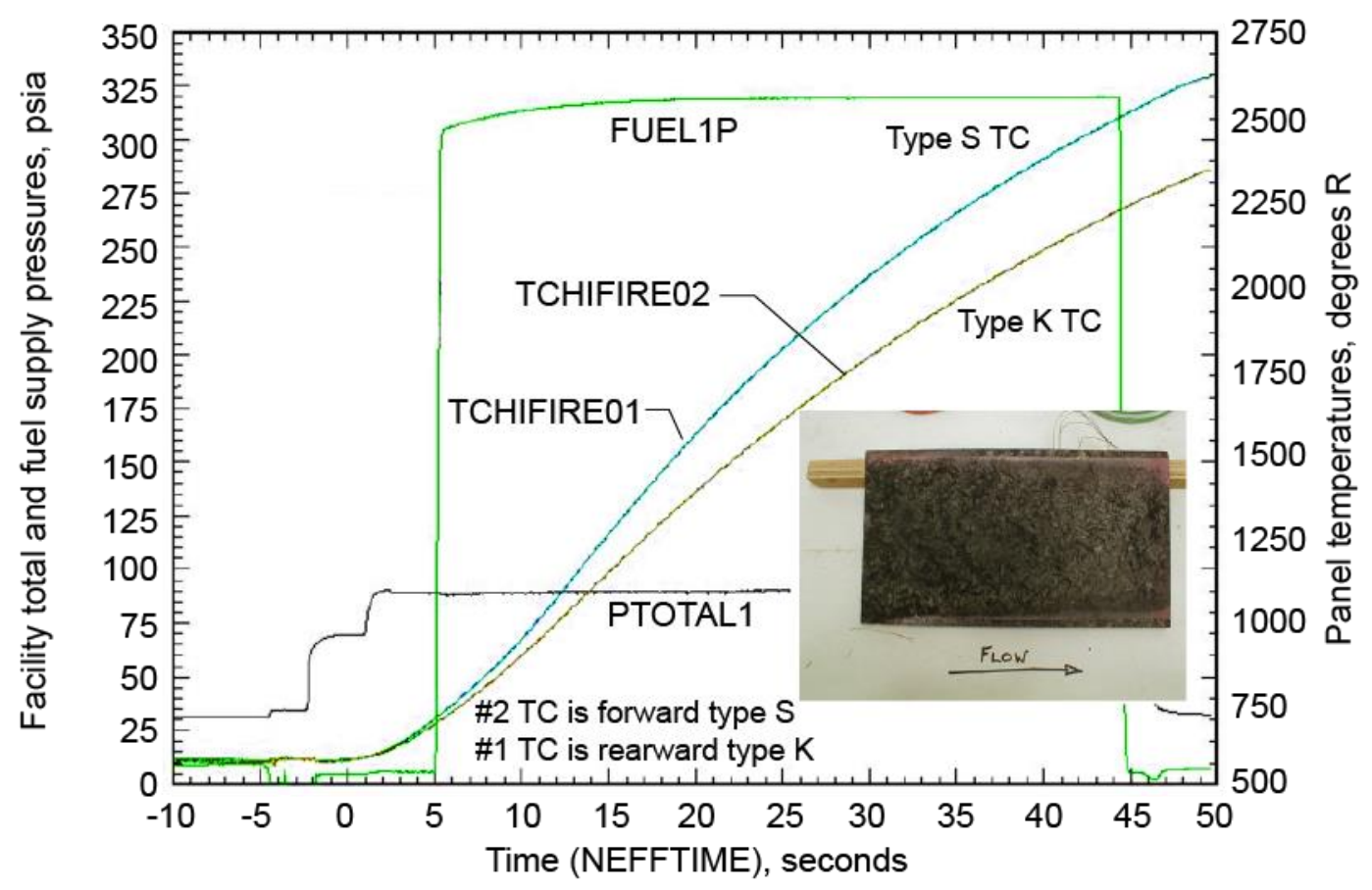

Figure 20. C/C panel test temperatures during Run 75.

A photograph of the C/C test panel posttest is shown in Figure 21. As shown in Table 4, the panel was tested for 100 seconds at Mach 5 conditions, and 193 seconds at Mach 6 conditions. The measured recession data are shown in Table 6, as well as graphically in Figure 22.

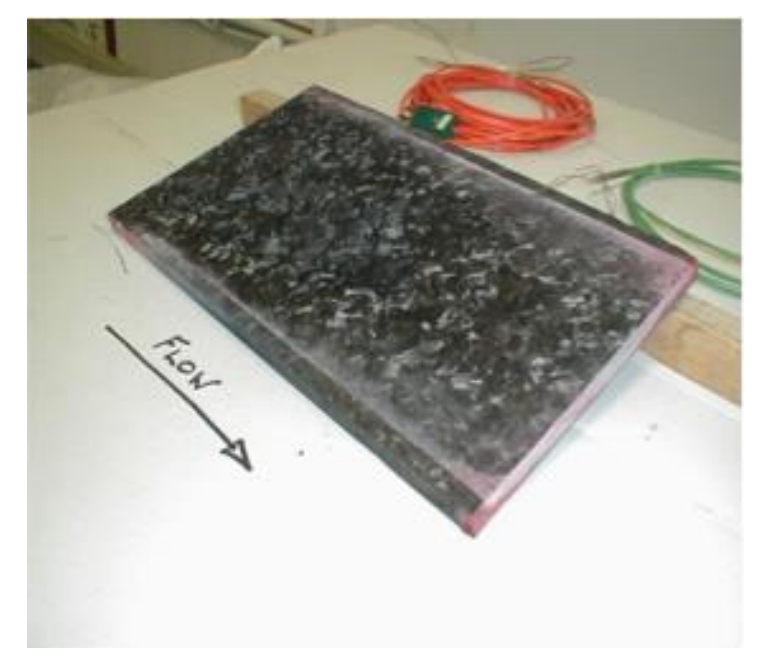

Figure 21. Post-test photograph of C/C panel HP635-7.

Table 5. Pre-and post-test thickness measurements for $\mathrm{C} / \mathrm{C}$ panel HP635-7.

\begin{tabular}{|c|c|c|c|c|c|c|c|c|}
\hline & \multicolumn{7}{|c|}{ Thickness (mm)/ Measurement location } \\
\hline & $\mathbf{1}$ & $\mathbf{2}$ & $\mathbf{3}$ & $\mathbf{4}$ & $\mathbf{5}$ & $\mathbf{6}$ & $\mathbf{7}$ & $\mathbf{8}$ \\
\hline Pre-test & 10.008 & 10.008 & 10.008 & 10.008 & 10.084 & 10.109 & 9.957 & 9.931 \\
\hline Post-test & 9.881 & 9.881 & 9.957 & 9.881 & 9.830 & 9.627 & 9.855 & 9.881 \\
\hline
\end{tabular}

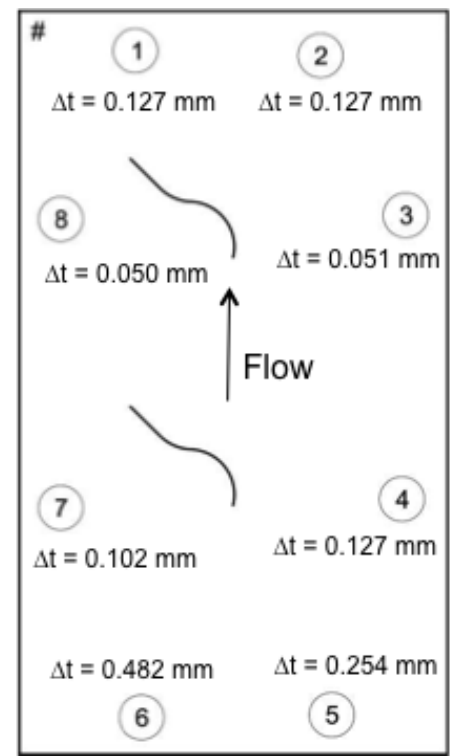

Figure 22. Recession measured after Run 75 on C/C panel HP635-7. 


\section{Approved for Public Release}

\section{Post-test Investigation of C/C-SiC Panels}

Several of the test panels were fabricated from $\mathrm{C} / \mathrm{C}-\mathrm{SiC}$ material as described previously. The surface that was to be exposed to the exhaust flow of the combustor was intentionally not machined in order not to remove the asfabricated $\mathrm{SiC}$ layer that forms as the result of the material processing. The backside of the panels was machined and grooves for thermocouple installation were created (see Figure 10). Post-test investigations were performed with samples from all three tested $\mathrm{C} / \mathrm{C}-\mathrm{SiC}$ panels. Since the findings were consistent between the three panels, the process is described for panel \#1 only.

A number of samples were prepared on the centerline of the panel and on a line that was $20 \mathrm{~mm}(0.79 \mathrm{in}$.) from the side edge of the panel. The panel was cut into 19 pieces, and each piece was numbered accordingly. The samples were prepared for investigations in the scanning electron microscope (SEM), i.e. they were embedded in a packing material and the surface to be investigated was ground and polished. For the investigations presented here, two samples from each panel were prepared. These were the cut-outs \#5 and \#17 from the centerline, as shown in Figure 23. Cut-out \#5 was upstream on the panel closest to the combustor. Cut-out \#17 was on the downstream end of the panel close to the nozzle exit.

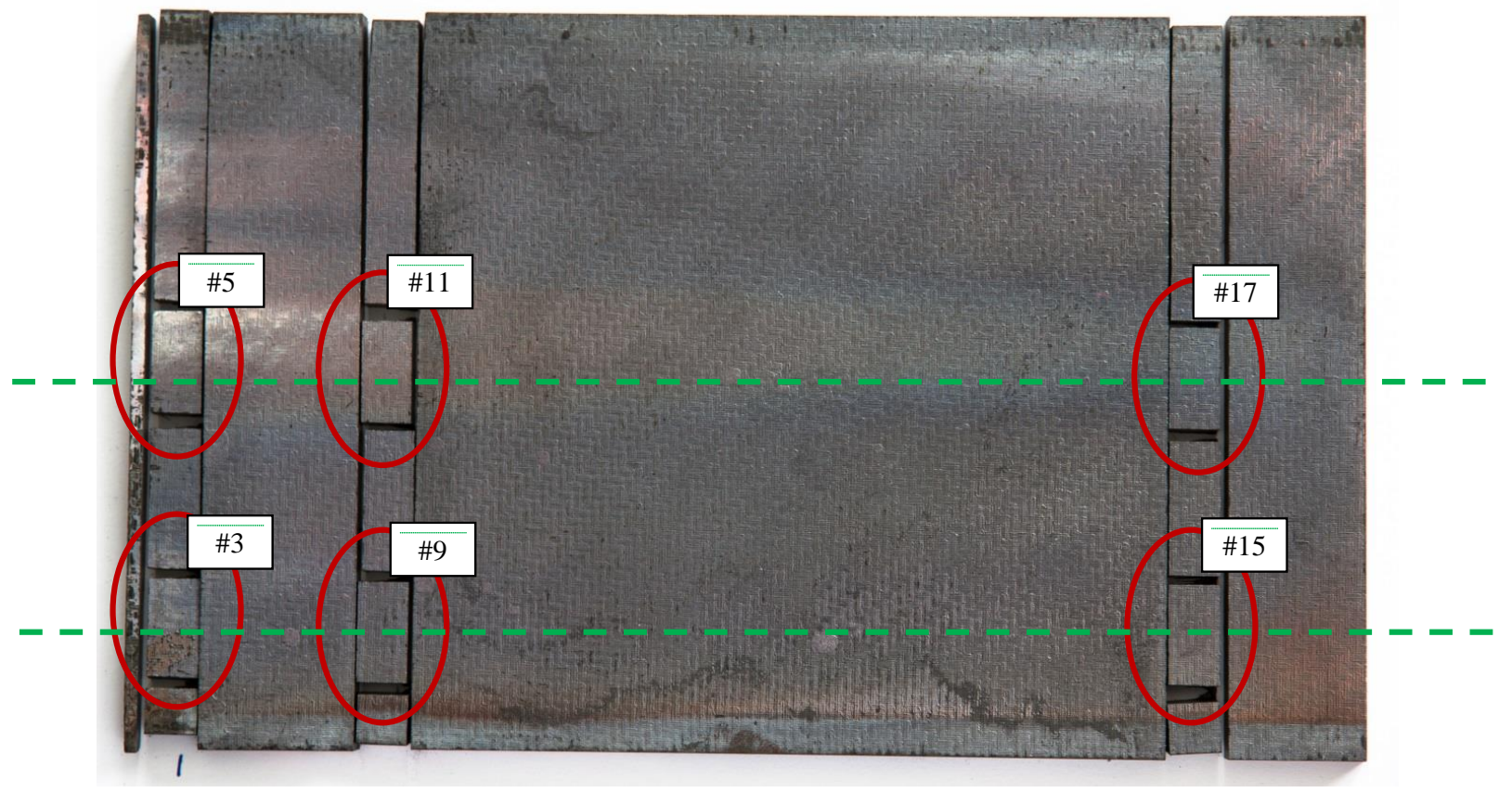

Figure 23. Panel 1 with cut pattern for the sample preparation.

Figure 24 shows an SEM image with the typical C/C-SiC microstructure. Carbon fiber bundles are separated by crack volumes that are filled with $\mathrm{SiC}$ at the boundaries and $\mathrm{Si}$ in the case when the width of the pore or crack is comparatively large. The surface of the sample is not flat because it was not machined, so the topology of the fiber textile is seen. The area on the top part of the image where numerous bright spots appear is the packing material used for embedding the sample.

There is no evidence of significant oxidation, which might have resulted in degraded fibers or matrix near the surface. What can be seen, is a thin bright layer on the surface that was identified as silicon dioxide $\left(\mathrm{SiO}_{2}\right.$ or silica) using electron diffraction spectroscopy (EDX) analysis.

The close-up of the detail highlighted in Figure 24 is shown in Figure 25. The different material phases can be distinguished very well. There is a fiber bundle with $\mathrm{SiC}$ on the surface. On the surface, above the $\mathrm{SiC}$ is a thin layer of silica $\sim 20 \mu \mathrm{m}\left(0.0008 \mathrm{in}\right.$.) thick. The $\mathrm{SiO}_{2}$ layer on the surface does not have a constant thickness in every location over the sample. There are some spots where no $\mathrm{SiO}_{2}$ layer can be found and there are locations with a thinner layer, but in general, there is a $\mathrm{SiO}_{2}$ layer over most of the sample. 

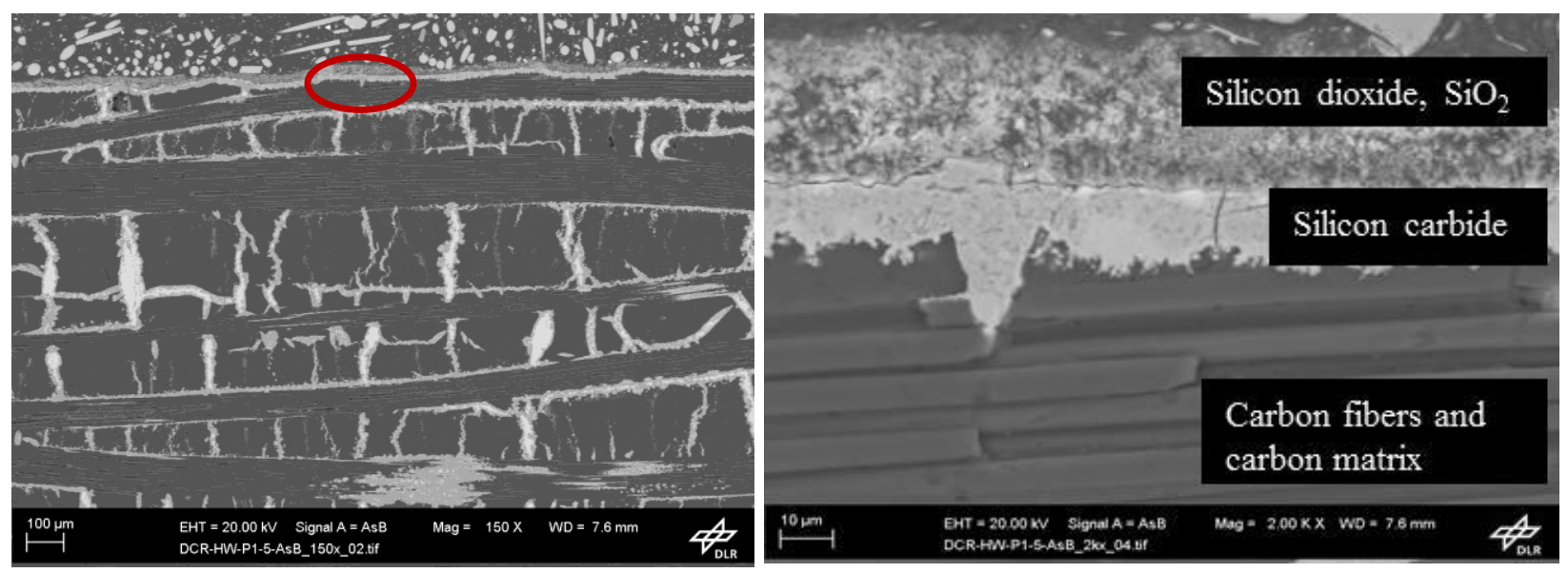

Figure 24. SEM image of sample \#5 from panel 1. There is a thin layer on the surface that is Figure 25. SEM image of the $\mathrm{SiO2}$ scale on top identified as silica. Red circle indicates area that is surface of the sample. shown in higher magnification in Figure 25.

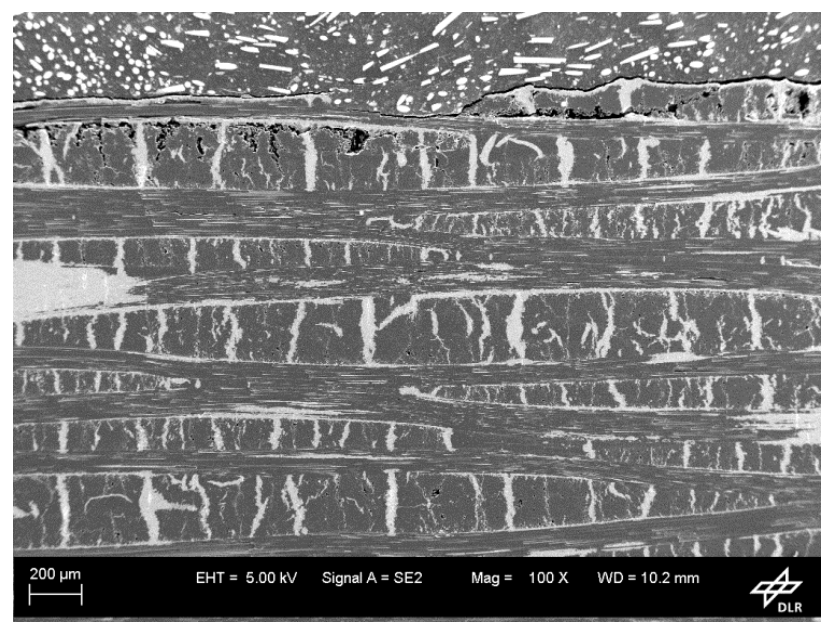

Figure 26. SEM overview image of sample \#17 from panel 1, exposed surface is on the top.

Figure 26 shows the surface of sample \#17 from the end of the panel. There are a few cracks and pores in the two topmost layers. These could be the result of oxidation of the carbon since close-up images show signs of oxidation in the pores at fiber ends and on the matrix. However, the amount of pores was significantly smaller in other samples, so in part they can also be the result of sample preparation as there is a tendency of sample material to break out at the edges due to the relative softness of the surrounding packaging. Figure 27 shows a close-up SEM image showing some indication of matrix oxidation in the pore.

Note the clean-cut ends of most of the fibers as the result of the preparation. The circle indicates the region detailed in Figure 28.

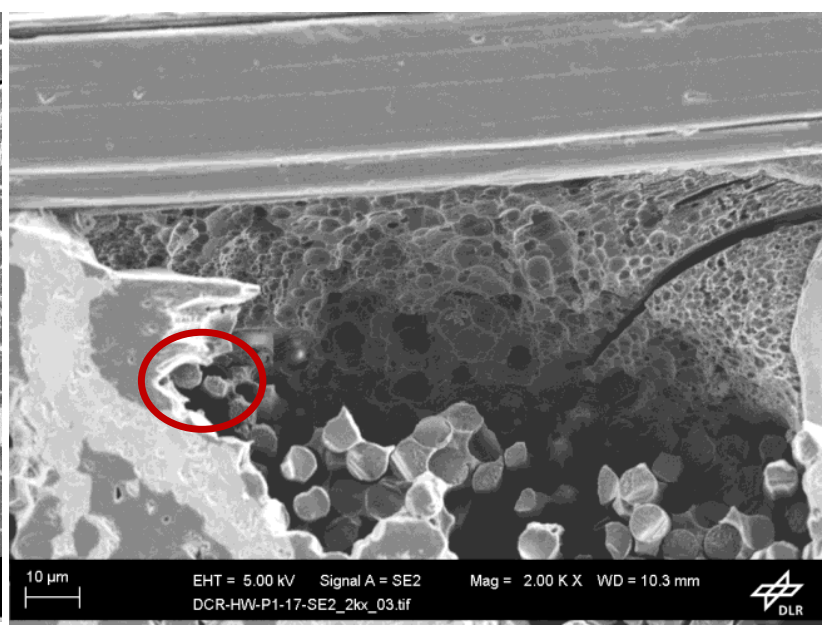

Figure 27. Close-up SEM image showing some indication of matrix oxidation in the pore.

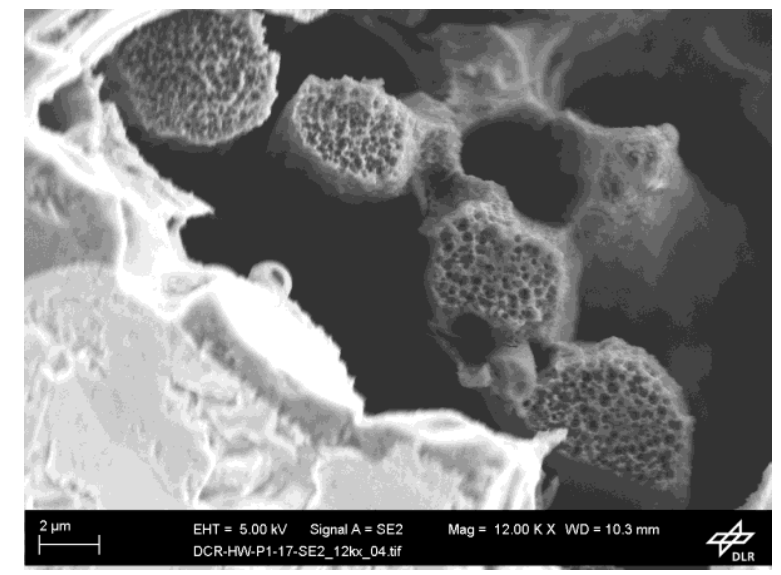

Figure 28. SEM image of fiber ends that have a rough cross-section, which is interpreted as the effect of oxidation. 


\section{Approved for Public Release}

\section{Concluding Remarks}

The DLR C/C and C/C-SiC materials were tested at NASA Langley Research Center in a high-enthalpy directconnect test facility at conditions simulating flight at Mach 5 and Mach 6 for several minutes. The $\mathrm{C} / \mathrm{C}$-SiC survived the high-temperature scramjet combustor environment with very little erosion. The $\mathrm{C} / \mathrm{C}$ material experienced slightly more erosion, but still only a small amount. SEM analysis of the tested panels indicated very little oxidation of the exposed surface. The HIFiRE 8 flight, for which the materials were tested, is planned for Mach 7 for $\sim 30 \mathrm{sec}$. Due to the successful performance of the test panels, the DLR C/C-SiC material is being considered for use as a passive combustor on the HIFiRE 8 flight vehicle.

\section{Acknowledgement}

The technical effort reported herein was sponsored by the Hypersonic International Flight Research and Experimentation (HIFiRE) Program Office under an international collaboration between the Air Force Research Laboratory (AFRL) and the Australian Defence Science and Technology Organisation (DSTO). Specific Authority was secured under the terms and conditions of Project Arrangement (PA) AF-06-0046, and subject to terms and conditions secured under the joint US DoD-DoD Australia Memorandum of Understanding (MOU) for Co-operative and Collaborative Research, Development and Engineering.

\section{References}

${ }^{1}$ Gosse, R., Kimmel, R., and Johnson, H. B., "Study of Boundary-Layer Transition on Hypersonic International Flight Research Experimentation 5," Journal of Spacecraft and Rockets, Vol. 51, 2014, pp 151-162.

${ }^{2}$ Smart, M. K., Hass, N. E. and Paull, A., "Flight Data Analysis of the HyShot 2 Flight Experiment," AIAA Journal, Vol. 44, No. 10, 2006, pp 2366-2375.

${ }^{3}$ Guy, R. W., Rogers, R. C., Puster, R. L., Rock, K. E., and Diskin, G. S., "The NASA Langley Scramjet Test Complex," (AIAA-96-3243), AIAA, ASME, SAE, and ASEE, Joint Propulsion Conference and Exhibit, 32 ${ }^{\text {nd }}$, Lake Buena Vista, FL, July 1-3, 1996.

${ }^{4}$ Krenkel, W., Ceramic Matrix Composites, ISBN 978-3-527-31361-7 - Wiley-VCH, Weinheim, 2008. 